\section{Institutionalizing torture in Israel: The Firas Tbeish decision. A commentary by John W. Schiemann, PhD*}

Efrat Shir's article in this volume, "How do you say IP in Hebrew? The case of Mr. Firas Tbeish," provides a valuable service by documenting the difficulties surrounding the recognition of the Istanbul Protocol by the Israeli Supreme Court, in a discussion of the court's 2018 ruling in Firas Tbeish v. The Attorney General (FT). Shir rightly notes that the court's "reasoning behind the decision was ... disturbing." In the course of her analysis she raises two important questions:

1. "How does one prove ... [having been tortured when] ... interrogations are not recorded, medical files are lacking and interrogees' rights frequently ignored?"

2. "If an IP assessment is not significant, how can claims that interrogational methods cause great pain and suffering be established?"

The implicit answers to these questions from the state of Israel are: 1. "one can't" and 2. "they can't" respectively.

Shir's examination explains the background to these responses by revealing the systematic efforts by both the government

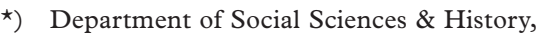
Fairleigh Dickinson University, Madison, New Jersey

Correspondence to: jws@fdu.edu of Israel and its highest judicial body to institutionalize torture. On the one hand, the government, Shir notes, "has neither outlawed nor defined torture in domestic legislation" yet has crafted secret guidelines to regularize its use. On the other hand, the Supreme Court pursues its own three-pronged strategy that effectively institutionalizes torture, something Shir shows in part by referring briefly to another case brought by The Public Committee Against Torture in Israel (PCATI), $A s^{\prime} a d A b u$ Gosh et al. $v$ the Attorney General et al. (2017).

First, the court simply ignores certain claims (e.g. cruel, inhuman or degrading treatment) and evidence (e.g. psychological trauma) entirely. Second, it treats the absence of evidence of torture in the form of ISA medical records as evidence of the absence of torture. Such rulings sustain a system that "overtly views torture as physical and expects visible damage" and so provides further incentive to ISA officials to simply not record any injuries from abuse. Third, the court not only fails to "train its own investigators and judges" in the IP, but also actively "disparage[s]" and dismisses its evidentiary weight by referencing the (necessary) lapse of time between torture and IP examination on the one hand, and discounting statements by the victim on the other hand.

Several additional aspects of the court's decision weaken existing minimal restraints on torture in Israel and are certain to encourage its continued use and likely expansion: attempts at legal and normative justifications for torture, further bureaucratization of torture, and providing ex ante legal cover.

\section{Attempts at legal and normative justifications for torture}

The FT decision raises profound concerns 
about the legal and normative justification for torture by the Israeli state. There are two issues with the legal justification. First, the decision equates the successful elicitation of information under torture with its lawfulness. In several places the decision states very explicitly that the abuse was legally justified by the successful elicitation of information ( $F T$, paras $9,26,59)$. On this view any torture can be justified if it results in information. The court avoided addressing whether torture is justified if it fails to generate information, but there are two possibilities: either torture is justified despite the failure or it is not. The former position would "give a green light" to torturing under any conditions because it is justified even if little or no information is elicited. If, on the other hand, the court holds that the failure to elicit information means the torture was unjustified, it has the perverse effect of directly contradicting the court's own rationale and justification for torture where the detainee actually had information but refused to divulge the known information despite the torture.

The second problem as concerns legal justification is the court's finding that the torture was lawful because the means "were proportionate relative to the serious threat" ( $F T$, para 59; also Justice I. Amit concurring, para 2). Here, the court creates new law without factual grounding. Israel is party to the Convention against Torture, which thus has binding legal force. Paragraph two of Article two explicitly states that "[n]o exceptional circumstances whatsoever, whether a state of war or a threat of war, internal political instability or any other public emergency, may be invoked as a justification of torture." There is nothing in this provision, nor anywhere else in the treaty, that comes close to mentioning, let alone providing, exculpatory exceptions related to proportionality.

Nor can the court find support in its own 1999 landmark decision outlawing torture in Public Committee against Torture v. State of Israel (PCATI). That decision refers to proportionality but only in the context of the possibility for an investigator to claim a necessity defense after the fact, whilst very explicitly not making the abuse itself lawful.

Moreover, even here, the language of the 1999 decision respects the non-derogable character of the prohibition by explicitly noting that the proportionality must never rise to the level of torture. In the court's 1999 language, "an investigator who, in the face of such danger, applies a degree of physical pressure, which does not constitute abuse or torture of the suspect, but is proportionate to the danger to human life can, in the face of criminal liability, avail himself of the "necessity defense"" (PCATI, para 16). The decision goes on (PCATI, para 23) to reaffirm that " $[t]$ hese prohibitions are "absolute." There are no exceptions to them and there is no room for balancing."

In addition to ignoring the treaty to which it is a party and making up its own law, the court's decision also begs the question as to whether a bigger perceived threat would justify measures even the Israeli court would deem torture. Indeed, at least one justice -- D. Mintz -- already seems to thinks so, given a passing remark in his concurring opinion "that torture is prohibited, apart from extremely exceptional cases," despite the fact that torture is absolutely prohibited in Israeli law (FT, para 3). A follow up ruling on the same case (HCJ 9105/18) by the Chief Justice noting that Mintz's comment was "inaccurate" does little to assuage such fears.

With respect to the broader normative justification, according to this decision 
not only does the bomb not really need to tick, but it may not even be likely to go off. Shir correctly notes that the ticking bomb hypothetical has been the paradigmatic justification - the "necessity defense" in Israeli legal terms - for Israeli (and other countries') interrogational torture. The Firas Tbeish decision broadens the scope of the necessity defense beyond PCATI - which already allowed the requirement to be met even when the danger may be realized "in a few days, or even in a few weeks"-by now weakening the requirement that the threat be certain (PCATI, para 34). In the words of the court, the threat is now "might ... cost human lives" (FT, para 60) rather than the 1999 decision language requiring that "the danger is certain to materialize" (PCATI, para 34). In sum, both the legal and normative justifications in the decision weaken the prohibition on torture and increase its likelihood.

\section{Bureaucratization of torture}

The court's approval of the ISA's three internal torture guidelines discussed in the decision effectively serve to further bureaucratize torture in Israel. The first guideline sets out a consultation system permitting superiors to opine to subordinates that torture ("special measures") is "immediately required" but "who cannot authorize" the torture (FT, para 28 ). In a security agency with a quasi-military chain of command, the scholastic exercise of differentiating between an opinion and an order by a superior is artificial, and is a de facto directive to torture. Consistent with this reality and inconsistent with the guideline's pretense of expressing opinion only, superiors can, however, set limits on the torture employed according to the second guideline. Thus, by setting limits on discretion about when to torture, the ISA effectively defines the conditions under which it can be employed ex ante and so triggers torture when those conditions are deemed to have been met. The third guideline completes the bureaucratization by outlining how torture should be memorialized for the record. Nothing says bureaucratized like a requirement to fill out the proper forms.

And yet, despite all this, as well as the court's own 1999 finding in PCATI that 'the necessity defense' does not constitute a source of authority which would allow ISA investigators to make use of physical means during the course of interrogations (PCATI, paras 36-38), in 2018 the court refused to draw the obvious conclusion that such a combined system does indeed constitute "a predetermined, systematic canon" for the use of torture or "general, advance instruction or direction" (FT, paras 64,65$)$. Indeed, the court instead praised the system for "actually serv[ing] to protect the interrogee from an unlawful infringement of his rights" and, in the words of Justice Mintz, "may moderate the very use of" torture and "facilitate its better implementation" ( $F T$, para 65 ; Justice D. Mintz, concurring, para 3). This is part and parcel of what legal scholar David Luban called the "fantasy" of "fastidious" and limited torture central to the view that torture is compatible with liberal democracy because it "can be neatly confined to exceptional ticking-bomb cases and surgically severed from cruelty and tyranny" (Luban 2005, 1452, 1461). The actual result, however, is a "torture culture, a network of institutions and practices that regularize the exception and make it standard operating procedure" (Luban $2005,1461)$. In short, together these rules enable torturing with impunity by helping to systematize a practice the 1999 PCATI decision prohibited. 


\section{Ex ante legal cover}

Although the PCATI decision criminalized torture, it also left open the possibility for ex post facto exoneration if the criteria for the necessity defense had been met. This exception had already, in Shir's phrasing, "left the door open" to legal torture by permitting "the State Attorney General to establish his or her own guidelines in regard to security interrogations." The current decision throws the door wide open by claiming that the necessity defense is not merely exculpatory but justificatory. Based on a vague reference to "some criminal law theories," "the result of the application of the necessity defense is, therefore, not merely the exoneration of the actor, but also the justification of the act, such that it is not defined as a harmful phenomenon that the criminal law seeks to prohibit" (FT, para 61$)$. This again is creating law without grounding in facts and signals ex ante legal cover to ISA officials who decide to torture, thus incentivizing its continued and expanded use.

\section{Turning a blind eye to torture}

In sum, Shir's article shows that with this decision the court signaled that it will continue to use the blindfold of justice to keep its eyes closed to torture by the ISA, whatever the evidence and despite the court's explicit reference to the definition of torture in the Convention Against Torture, to which Israel is a party. The court simply takes witness (interrogators, medical personnel, guards) denials of abuse in the government's internal investigations at face value (e.g. $F T$, paras 17,49 ). The court also deems the absence of evidence in medical records as the evidence of absence (of torture), rather than opening an investigation about problems with the documentation (FT, para 52).
Second and in sharp contrast, the court treats statements and evidence submitted by FT very differently, placing great weight on minor inconsistencies in FT's account over time, questioning FT's inability to recall certain details of his torture (a wellknown sequel of torture-induced trauma), and his refusal to take a polygraph test at that stage of the process ( $F T$, para 49). Third, the court not only takes at face value the claim by ISA interrogators that the "scope and nature" of their "special interrogation means" "differed significantly from" FT's claims of shaking, stress positions like the frog, and sleep deprivation, but also fails to provide any method or test by which they determined that those differences, even if true, were sufficient not to constitute torture. Further, in FT (para 47), just prior to finding no suspicion of criminal offense by the ISA in para 48 , the court dismissively refers to the stress positions "as improper "torture methods," as a mere claim by FT in scare quotes when in fact, as Shir states, this was the very finding of PCATI:

"Consequently, it is decided that the
order nisi be made absolute. The [ISA]
does not have the authority to "shake" a
man, hold him in the "Shabach" position
(which includes the combination of various
methods, as mentioned in paragraph 30),
force him into a "frog crouch" position and
deprive him of sleep in a manner other than
that which is inherently required by the
interrogation (PCATI, para 40)."

Parenthetically, note that it is clear by the court's use of "inherent" elsewhere in the 1999 decision that it means a possible need to question a prisoner when he might otherwise sleep and not that successful interrogation requires depriving a detainee of 
sleep in order to "break" him, i.e. deliberate sleep deprivation as an interrogation method. For example, the court notes that seating the prisoner is inherent to the interrogation, but seating him in the shabach stress position is not inherent to an interrogation and is therefore prohibited (PCATI, 1999, para 27).

Lastly, the injuries to Firas Tbeish and his description of the techniques used against him (e.g. the "frog" and "banana") are consistent with the by now very wellestablished public knowledge of ISA torture practices, based not just on detainee reports but by human rights groups and even interrogator revelations ( $F T$, para 10; Absolute Prohibition 2007, 67; Amnesty International 2016, 23; Levinson 2017). The court took the ISA's claims at face value that instances of torture have been sharply reduced to a "tiny percentage" when a 2015 investigative report by Haaretz and the Public Committee Against Torture in Israel found that torture by interrogators was on the rise (FT, para 44; Levinson 2015). Despite this, as Shir notes, "of over 1,200 complaints of torture that have been submitted during nearly two decades, no ISA interrogator has ever been indicted."

In her discussion of the court's dismissal of the IP, she says there "is a legal system that discredits the IP's potential while digging deeper into its own conception of torture." Shir has helped show that this is true more broadly of torture, beyond the IP. Indeed, I suspect the court may not view the IP as a "strange creature" causing "suspicion of the unfamiliar." Instead, it may be by now a very familiar creature that threatens torture's impunity in Israel, and what Shir shows is that the court has developed a systematic strategy to counter it. Torture is possible in Israel because the government and courts are complicit in deliberately creating a legal and institutional black hole where boundaries are ill-defined and obscure, and no light can shine.

References

B'Tselem and HaMoked. (2007). Absolute Prohibition: The Torture and Ill-treatment of Palestinian Detainees. Retrieved from https://www.btselem. org/sites/default/files/sites/default/files2/ publication/200705_utterly_forbidden_eng.pdf

Firas Tbeish et al. v the Attorney General et al., HCJ 9018/17 (2018). Retrieved from http:// stoptorture.org.il/wp-content/uploads/2017/02/F.Tbeish-Ruling-Nov. 2018.ENG_.pdf

Public Committee Against Torture v State of Israel, HCJ 5100/94 (1999). Retrieved from https://supremedecisions.court.gov.il/Home/ Download?path=EnglishVerdicts $\backslash 94 \backslash 000 \backslash 51 \backslash$ a09\&fileName $=94051000 \_a 09$. txt\&type $=4$

Firas Tbeish et al. v the Attorney General et al., HCJ 9105/15 (2018) (in Hebrew). Retrieved from http://stoptorture.org.il/wp-content/ uploads/2019/02/-1קותמ-שיבט-הטלחה-1.pdf

Amnesty International. (2016). Israel: Submission to the United Nations Committee Against Torture by Amnesty International, 57th Session, 18 April-13 May 2016.

Levinson, C. (2017, Jan 24). Torture, Israelistyle -- as Described by the Interrogators Themselves. Haaretz. Retrieved from https:// www.haaretz.com/israel-news/.premium-israelistyle-torture-as-described-by-the-interrogatorsthemselves-1.5489853

Levinson, C. (2015, March 6). Torture of Palestinian Detainees by Shin Bet Investigators Rises Sharply. Haaretz. Retrieved from https://www. haaretz.com/.premium-torture-by-shin-betinvestigators-rises-sharply-1.5332951.

Luban, D. (2005). Liberalism, Torture, and the Ticking Bomb. Virginia Law Review, 91, 14251461. doi: 10.1007/978-1-4020-4678-0_15 